\title{
The Effect of Acupuncture Therapy on Reducing Blood Pressure in Hypertension Patients: Meta-Analysis
}

\author{
Faricha Indra Hapsari'1), Setyo Sri Rahardjo²), Hanung Prasetya3) \\ 1)Masters Program in Public Health, Universitas Sebelas Maret \\ ${ }^{2)}$ Faculty of Medicine, Universitas Sebelas Maret \\ 3) Surakarta Health Polytechnic
}

\section{ABSTRACT}

Background: Acupuncture is a traditional Chinese medicine for treating ailments, including diseases of the cardiovascular system, such as hypertension. Acupuncture modulates neurohumoral regulatory systems and cardiovascular function. This study aims to estimate the effectiveness of acupuncture therapy in reducing blood pressure in hypertensive patients.

Subjects and Method: This was a systematic review and meta-analysis, with PICO, namely Population $=$ hypertension cases aged 20-80 years. Intervention $=$ acupuncture therapy. Comparison $=$ Sham $/$ Placebo $/$ No Treatment Acupuncture. Outcome $=$ Blood pressure. The articles used in this study were obtained from several databases including Google Scholar, MEDLINE/ PubMed, Science Direct, Hindawi, BMC, Europe PMC and Springer Link. These articles were collected for 1 month. The keywords to search for articles were as follows: "acupuncture", "hypertension", "randomized controlled trial", "hypertension randomized controlled trial", "acupuncture randomized controlled trial", "acupuncture for primary hypertension", "acupuncture for hypertension essential" AND "acupuncture for blood pressure". The articles included in this study are full text articles with a randomized controlled trial study design. Articles were collected using PRISMA flow diagrams and analyzed using the Review Manager application (RevMan) 5.3.

Results: A total of 9 articles were reviewed in this meta-analysis. Articles are from America, Germany, Korea, China, India and Taiwan. The study showed that acupuncture therapy was able to reduce systolic blood pressure with the Standardized Mean Different by 0.54 compared to sham acupuncture/placebo/no treatment $(\mathrm{SMD}=0.54 ; 95 \% \mathrm{CI}=-1.04$ to $-0.04 ; \mathrm{p}<0.05)$. Acupuncture reduced diastolic blood pressure 0.49 units $(\mathrm{SMD}=0.49 ; 95 \% \mathrm{CI}=-0.99$ to 0.02 ; p>0.05) compared to sham acupuncture/ placebo, but it was statistically non significant. Conclusion: Acupuncture can reduce systolic blood pressure, but it is less significant in reducing diastolic blood pressure in hypertensive patients.

Keywords: acupuncture, hypertension, high blood pressure.

\section{Correspondence:}

Faricha Indra Hapsari. Masters Program in Public Health, Universitas Sebelas Maret. Jl. Ir. Sutami 36A, Surakarta57126, Central Java. Email: farichaindrah@gmail.com Mobile: +6285647075776 .

\section{Cite this as:}

Hapsari FI, Rahardjo SS, Prasetya H (2021). The Effect of Acupuncture Therapy on Reducing Blood Pressure in Hypertension Patients: Meta-Analysis. J Epidemiol Public Health. 06(01): 125-133. https://doi.org/10.26911/jepublichealth.2021.06.01.12.

(c) (1) Journal of Maternal and Child Health is licensed under a Creative Commons (c) ${ }_{\mathrm{EY} \text { NC SA }}$ Attribution-NonCommercial-ShareAlike 4.0 International License.

BACKGROUND

e-ISSN: 2549-0273
Hypertension or high blood pressure is a pathophysiological condition of the body 
where there is an increase in blood pressure above $140 \mathrm{mmHg}$ systolic pressure and 90 $\mathrm{mmHg}$ diastolic pressure on two measurements with an interval of 5 minutes in a state of sufficient rest/quiet (Yulanda, 2017).

The World Health Organization (WHO) in 2015 showed that around 1.13 billion people in the world suffer from hypertension and the number continues to increase every year. It is estimated that in 2025 people with hypertension will reach 1.5 billion with a total mortality of 9.4 million people due to hypertension and complications (Ministry of Health, 2018).

Complications of disease by hypertension cause more severe damage, such as stroke, coronary heart disease, left ventricular hypertrophy (heart muscle), kidney failure, several other diseases related to blood vessels, to death (Rodiah, 2013). Considering that there are various complications from hypertension cases, and the side effects of using anti-hypertensive drugs, there are many complementary treatment options to lower BP safely in hypertensive patients such as acupuncture. Acupuncture is one of the traditional Chinese medicine to treat diseases, including those related to the cardiovascular system, such as hypertension (Liu et al., 2015).

Acupuncture modulates the neurohumoral regulatory system and cardiovascular function (Li et al., 2015). Acupuncture can reduce $\mathrm{BP}$ in hypertensive patients by decreasing plasma renin, aldo-sterone, and angiotensin II activity, increasing sodium secretion and changing plasma norepinephrine, serotonin, and endorphin levels (Wang et al., 2013). This study aimed to assess and estimate the effectiveness of acupuncture therapy in reducing BP in hypertensive patients based on the results of previous similar studies.

\section{SUBJECTS AND METHOD}

\section{Study Design}

This research is a systematic review and meta-analysis. This study uses secondary data in the form of data obtained from previous studies. The question posed by the researcher this time was the effect of acupuncture therapy on reducing blood pressure in hypertensive patients. The study was conducted by searching and selecting data from the results of tests conducted on all ethnicities, races and locations. The time of the selected test results is in the period 2001-2021. Article searches are carried out for a maximum of one month. The PICO used is as follows: Population= hypertension cases aged 20-80 years. Intervention $=$ acupuncture therapy. Comparison $=$ Sham $/$ Placebo $/$ Not Treatment with Acupuncture. Outcome= Blood pressure. The articles used in this study were obtained from several databases, including Google Scholar, MEDLINE/ PubMed, Science Direct, Hindawi, BMC, Europe PMC and Springer Link. These articles were collected for 1 month. The keywords to search for articles were as follows: "acupuncture", "hypertension", "randomized controlled trial", "acupuncture for hypertension", "hypertension randomized controlled trial”, "acupuncture randomized controlled trial”, "acupuncture for primary hypertension ", "acupuncture for hypertension essential” AND "acupuncture for blood pressure". The articles included in this study are full text articles with a randomized controlled trial study design.

\section{Population and Sample} Inclusion Criteria:
a. Full paper article with Randomized Controlled Trial (RCT)
b. The article has an appropriate title and is related to the effect of acupuncture on reducing $\mathrm{BP}$ in hypertensive patients 
c. Articles published in English and/or Indonesian

d. Include the results of the study in the form of the number of respondents, the mean value and the standard deviation (SD) value

e. The intervention in the experimental group was acupuncture (with inserting needle)

f. Sham/placebo acupuncture, non-acupuncture hypertensive treatment (lifestyle modification, medication) and nontreatment were allowed in the control group.

Exclusion Criteria:

a. Research conducted with non-RCT studies

b. RCT research using acupressure, herbs, moxibustion and transcutaneous electrical acupoint stimulation in the experimental group kelompok

c. Articles published before 2001 d. Research subjects suffer from secondary hypertension or non-essential hypertension.

\section{Study Variables}

The dependent variable is a decrease in blood pressure in hypertensive patients. The independent variables in this study were acupuncture therapy and Sham/ placebo Acupuncture.

\section{Data Analysis}

Previous articles were collected using PRISMA flow diagrams and analyzed using Review Manager (RevMan) 5.3 application.

\section{RESULTS}

This meta-analysis analyzed 9 primary studies from 3 continents, namely the Asian continent, covering countries: South Korea, China, India, and Taiwan. Continental Europe, including Germany, and South America, including Boston, America.

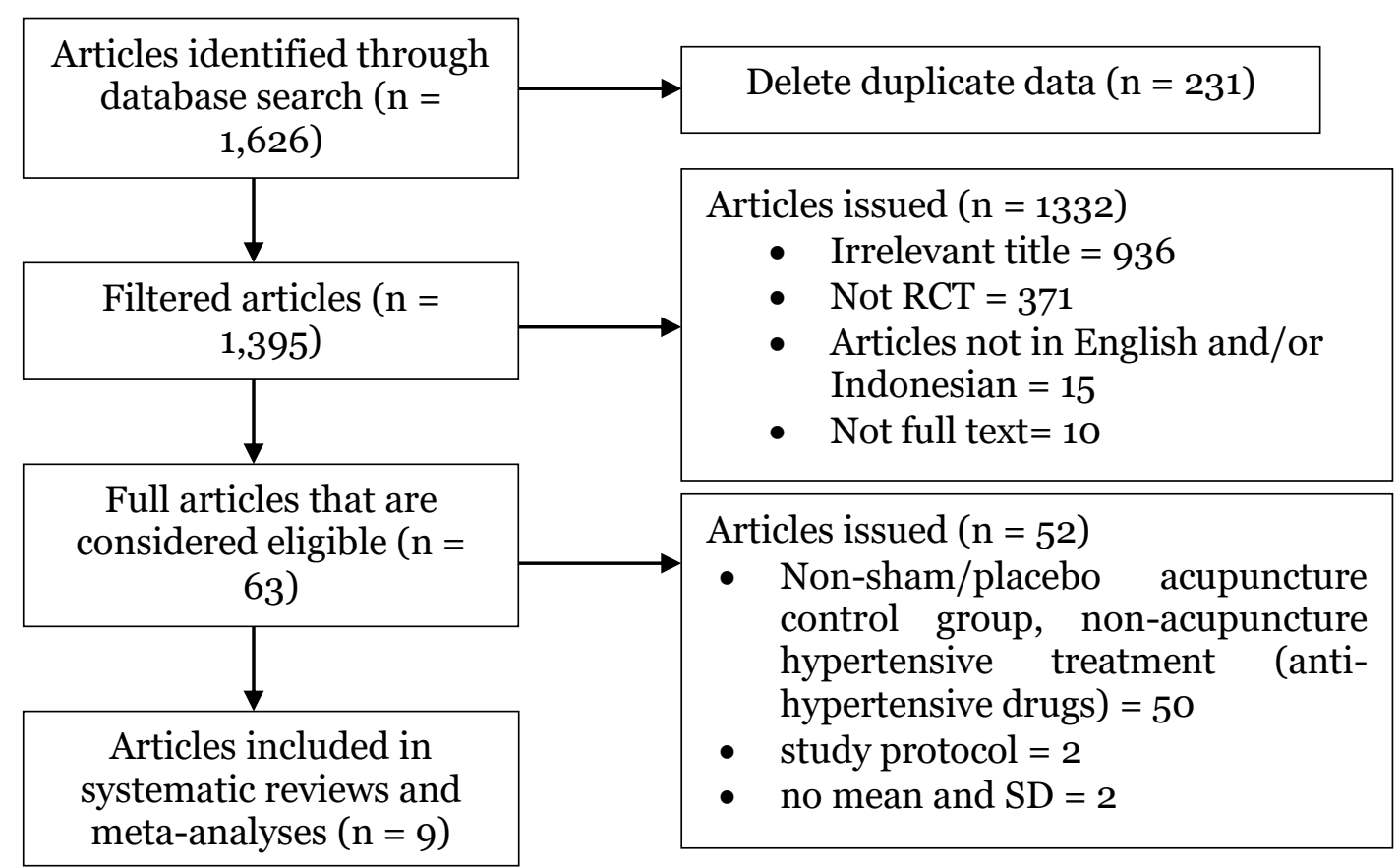

Figure 1. PRISMA flow diagram

The article search process has been carried out by searching for articles through a database based on the PRISMA flow diagram and can be seen in Figure 1. 
Hapsari et al./ Acupuncture Therapy on Reducing Blood Pressure in Hypertension Patients

The assessment of the quality of the articles used in this study is shown in table 1. In this instrument there are 12 questions (assessment items), if the answer is (Yes) it will be given a score of 1 and if the answer is (No) it will be given a score of o (CEBMa, 2014).

The result is the research quality score is between the numbers 11-12. This indicates that the research article has good quality for meta-analysis.

There are 9 Randomized Controlled Trial (RCT) studies as a source of data in a systematic review and meta-analysis on the effectiveness of acupuncture in reducing blood pressure in hypertensive patients. An overview of the PICO (Population, Intervention, Comparison, Outcome) used in this study can be seen in table 2.

\section{Table 1. Research Quality Assessment (Critical Appraisal)}

\begin{tabular}{|c|c|c|c|c|c|c|c|c|c|c|c|c|c|}
\hline Scoring Items & 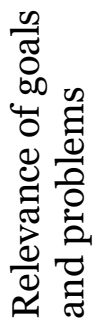 & 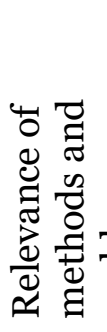 & 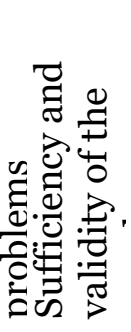 & 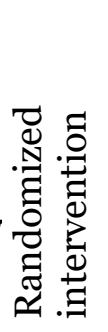 & 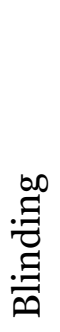 & 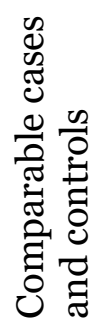 & $\frac{\sqrt[2]{0}}{\frac{0}{0}}$ & 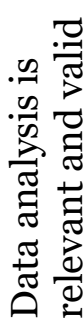 & 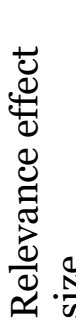 & 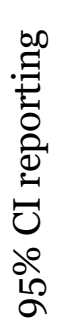 & 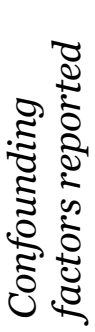 & 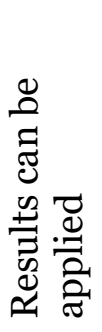 & 중 \\
\hline Maklin et al (2006) & 1 & 1 & 1 & 1 & 1 & 1 & 1 & 1 & 1 & 1 & 1 & 1 & 12 \\
\hline Flachskampf et al (2007) & 1 & 1 & 1 & 1 & 1 & 1 & 1 & 1 & 1 & 1 & 1 & 1 & 12 \\
\hline Yin et al (2007) & 1 & 1 & 1 & 1 & 1 & 1 & 1 & 1 & 1 & 1 & 1 & 1 & 12 \\
\hline Park et al (2010) & 1 & 1 & 1 & 1 & 1 & 1 & 1 & 1 & 1 & 0 & 1 & 1 & 11 \\
\hline Kim et al (2012) & 1 & 1 & 1 & 1 & 1 & 1 & 1 & 1 & 1 & $\mathrm{O}$ & 1 & 1 & 11 \\
\hline Liu et al (2015) & 1 & 1 & 1 & 1 & 1 & 1 & 1 & 1 & 1 & 1 & 1 & 1 & 12 \\
\hline Zheng et al (2019) & 1 & 1 & 1 & 1 & 1 & 1 & 1 & 1 & 1 & 1 & 1 & 1 & 12 \\
\hline Maheshkumar et al (2020. & 1 & 1 & 1 & 1 & 1 & 1 & 1 & 1 & 1 & $\mathrm{O}$ & 1 & 1 & 11 \\
\hline Huang et al (2020) & 1 & 1 & 1 & 1 & 1 & 1 & 1 & 1 & 1 & O & 1 & 1 & 11 \\
\hline
\end{tabular}

Note: Yes $=1$, No $=0$

Table 2. Description of the primary studies included in the meta-analysis

\begin{tabular}{|c|c|c|c|c|c|c|}
\hline Author & $\begin{array}{c}\text { Country } \\
\text { (Conti- } \\
\text { nent) }\end{array}$ & $\underset{\text { ple }}{\text { Sam }}$ & $\begin{array}{l}\text { P (Popula- } \\
\text { tion) }\end{array}$ & $\begin{array}{l}\text { I (Inter- } \\
\text { vention) }\end{array}$ & $\begin{array}{l}\text { C (Compa- } \\
\text { rison) }\end{array}$ & $\begin{array}{l}\text { O (Out- } \\
\text { come) }\end{array}$ \\
\hline $\begin{array}{l}\text { Maklin et al. } \\
(2006)\end{array}$ & $\begin{array}{l}\text { America } \\
\text { (South } \\
\text { America) }\end{array}$ & 192 & $\begin{array}{l}\text { Essential hyper- } \\
\text { tension patient }\end{array}$ & Acupuncture & $\begin{array}{l}\text { Sham Acupunc- } \\
\text { ture }\end{array}$ & $\begin{array}{l}\text { Blood } \\
\text { pressure }\end{array}$ \\
\hline $\begin{array}{l}\text { Flachskampfet } \\
\text { al. (2007) }\end{array}$ & $\begin{array}{l}\text { Germany } \\
\text { (Europe) }\end{array}$ & 160 & $\begin{array}{l}\text { Essential hyper- } \\
\text { tension patient }\end{array}$ & Acupuncture & $\begin{array}{l}\text { Sham } \\
\text { Acupuncture }\end{array}$ & $\begin{array}{l}\text { Blood } \\
\text { pressure }\end{array}$ \\
\hline $\begin{array}{l}\text { Yin et al., } \\
(2007)\end{array}$ & $\begin{array}{l}\text { South Korea } \\
\text { (Asia) }\end{array}$ & 41 & $\begin{array}{l}\text { Essential hyper- } \\
\text { tension patient }\end{array}$ & Acupuncture & $\begin{array}{l}\text { Sham } \\
\text { Acupuncture }\end{array}$ & $\begin{array}{l}\text { Blood } \\
\text { pressure }\end{array}$ \\
\hline $\begin{array}{l}\text { Park et al., } \\
\text { (2010) }\end{array}$ & $\begin{array}{l}\text { South Korea } \\
\text { (Asia) }\end{array}$ & 15 & $\begin{array}{l}\text { Essential hyper- } \\
\text { tension patient }\end{array}$ & Acupuncture & $\begin{array}{l}\text { Sham } \\
\text { Acupuncture }\end{array}$ & $\begin{array}{l}\text { Blood } \\
\text { pressure }\end{array}$ \\
\hline $\begin{array}{l}\text { Kim et al., } \\
(2012)\end{array}$ & $\begin{array}{l}\text { South Korea } \\
\text { (Asia) }\end{array}$ & 33 & $\begin{array}{l}\text { Essential hyper- } \\
\text { tension patient }\end{array}$ & Acupuncture & $\begin{array}{l}\text { Sham } \\
\text { Acupuncture }\end{array}$ & $\begin{array}{l}\text { Blood } \\
\text { pressure }\end{array}$ \\
\hline $\begin{array}{l}\text { Liu et al., } \\
\text { (2015) }\end{array}$ & $\begin{array}{l}\text { South Korea } \\
\text { (Asia) }\end{array}$ & 30 & $\begin{array}{l}\text { Essential hyper- } \\
\text { tension patient }\end{array}$ & Acupuncture & No intervention & $\begin{array}{l}\text { Blood } \\
\text { pressure }\end{array}$ \\
\hline $\begin{array}{l}\text { Zheng et al., } \\
\text { (2019) }\end{array}$ & China (Asia) & 428 & $\begin{array}{l}\text { Essential hyper- } \\
\text { tension patient }\end{array}$ & Acupuncture & $\begin{array}{l}\text { Sham } \\
\text { Acupuncture }\end{array}$ & $\begin{array}{l}\text { Blood } \\
\text { pressure }\end{array}$ \\
\hline $\begin{array}{l}\text { Maheshkumar } \\
\text { et al., (2020) }\end{array}$ & Iran (Asia) & 90 & $\begin{array}{l}\text { Essential hyper- } \\
\text { tension patient }\end{array}$ & Acupuncture & $\begin{array}{l}\text { Sham } \\
\text { Acupuncture }\end{array}$ & $\begin{array}{l}\text { Blood } \\
\text { pressure }\end{array}$ \\
\hline
\end{tabular}


Hapsari et al./ Acupuncture Therapy on Reducing Blood Pressure in Hypertension Patients

\begin{tabular}{llllll}
\hline $\begin{array}{l}\text { Huang et al., } \\
(2020)\end{array}$ & $\begin{array}{l}\text { Taiwan } \\
\text { (Asia) }\end{array}$ & 70 & $\begin{array}{l}\text { Essential hyper- } \\
\text { tension patient }\end{array}$ & $\begin{array}{l}\text { Acupuncture } \\
+ \text { anti hyper- } \\
\text { tension }\end{array}$ & $\begin{array}{l}\text { Blood hyper- } \\
\text { pressure }\end{array}$ \\
\hline
\end{tabular}

\section{Forest Plot Systolic}

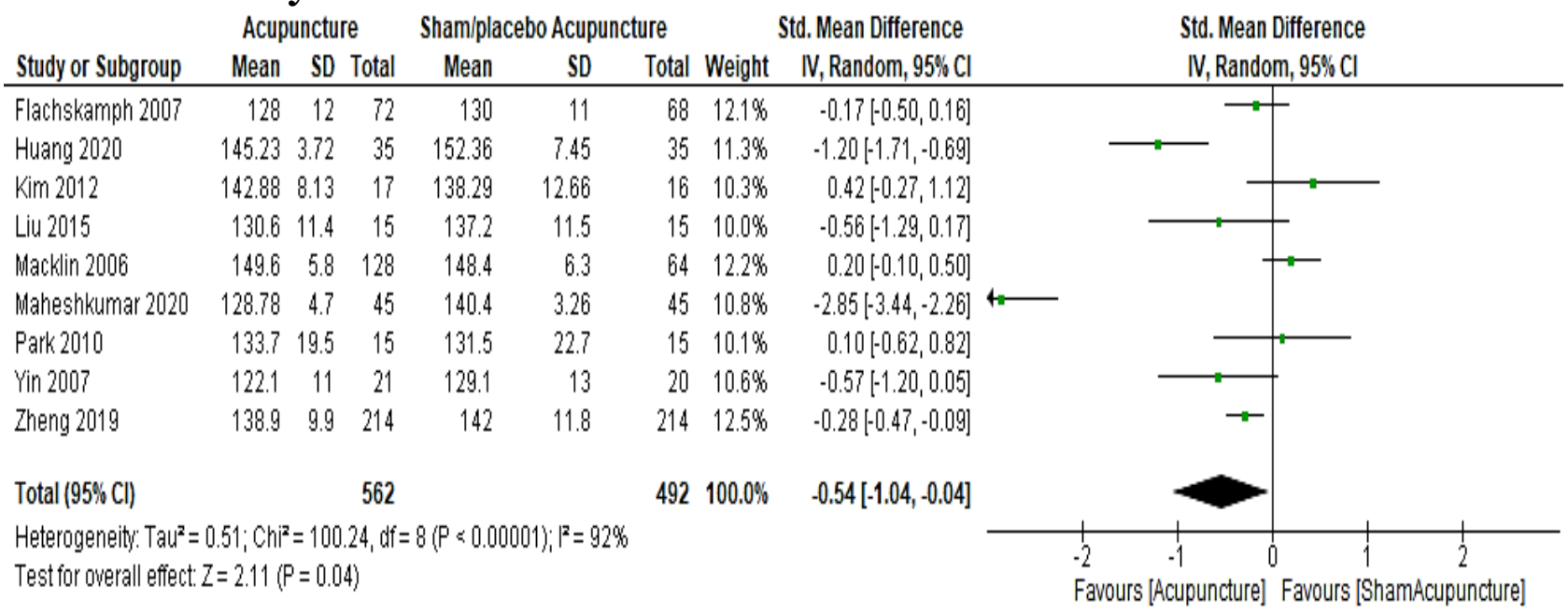

Figure 2. Forest plot of systolic blood pressure

\section{Funnel Plot Systolic}

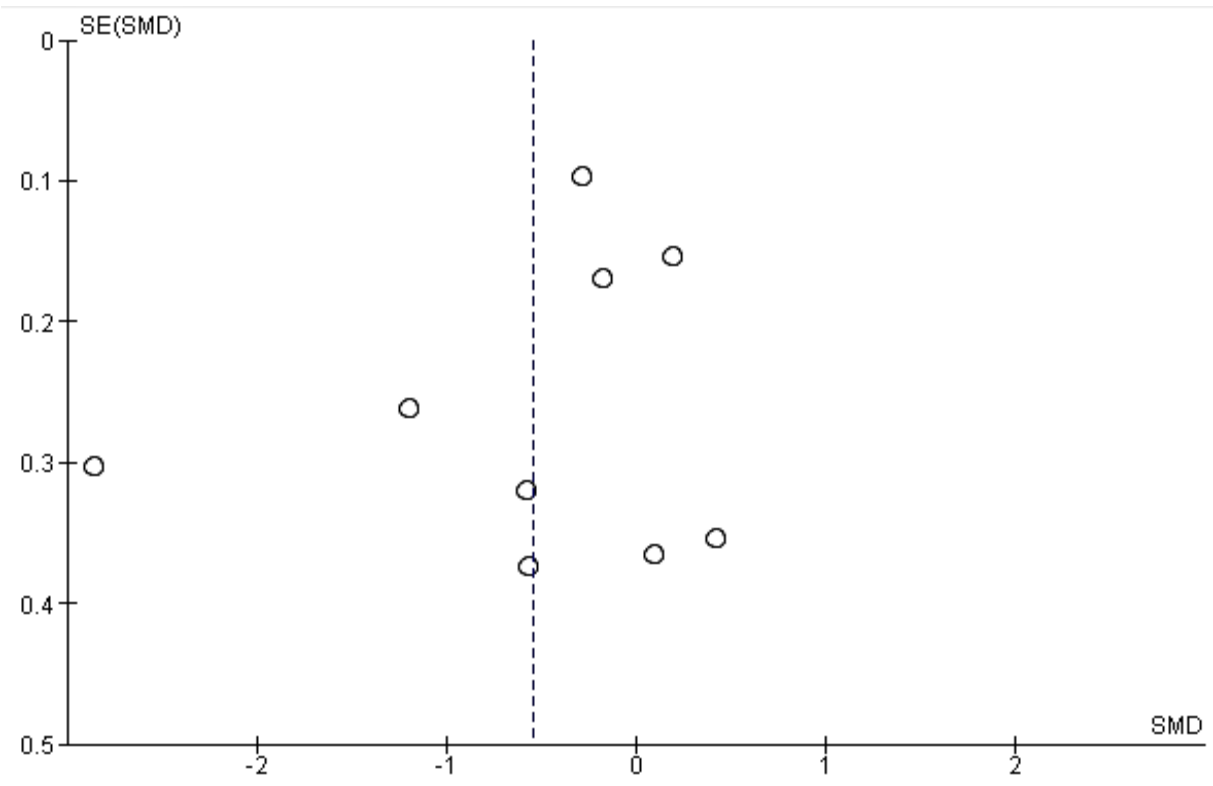

Figure 3. Funnel plot of systolic blood pressure

The interpretation of the results of the metaanalysis can be seen in Figure 2, for the forest plot of systolic blood pressure and Figure 3, for the funnel plot of systolic blood pressure. Based on the results of the analysis using RevMan 5.3 software, it is known that there is high heterogeneity $(=92 \%$; $p<$
0.001) so that the distribution of data is declared heterogeneous (Random Effect Model). Acupuncture therapy was able to reduce systolic blood pressure with Standardized Mean Different (SMD) by 0.54 compared to sham acupuncture $(\mathrm{p}=0.04)$. Based on Figure 3, there is a publication bias 
Hapsari et al./ Acupuncture Therapy on Reducing Blood Pressure in Hypertension Patients

which is characterized by an uneven

distribution of data. SE value $<0.5$.

3. Forest Plot Diastolic

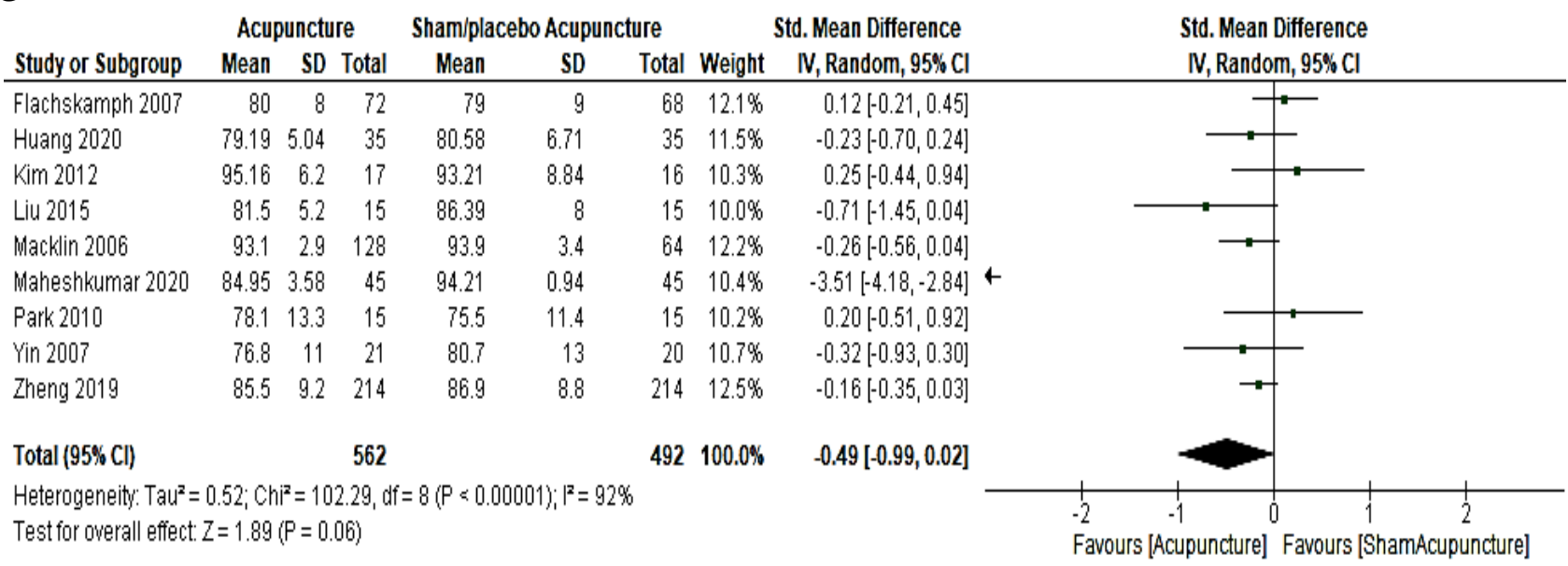

Figure 4. Forest plot diastolic blood pressure

\section{Funnel Plot Diastolic}

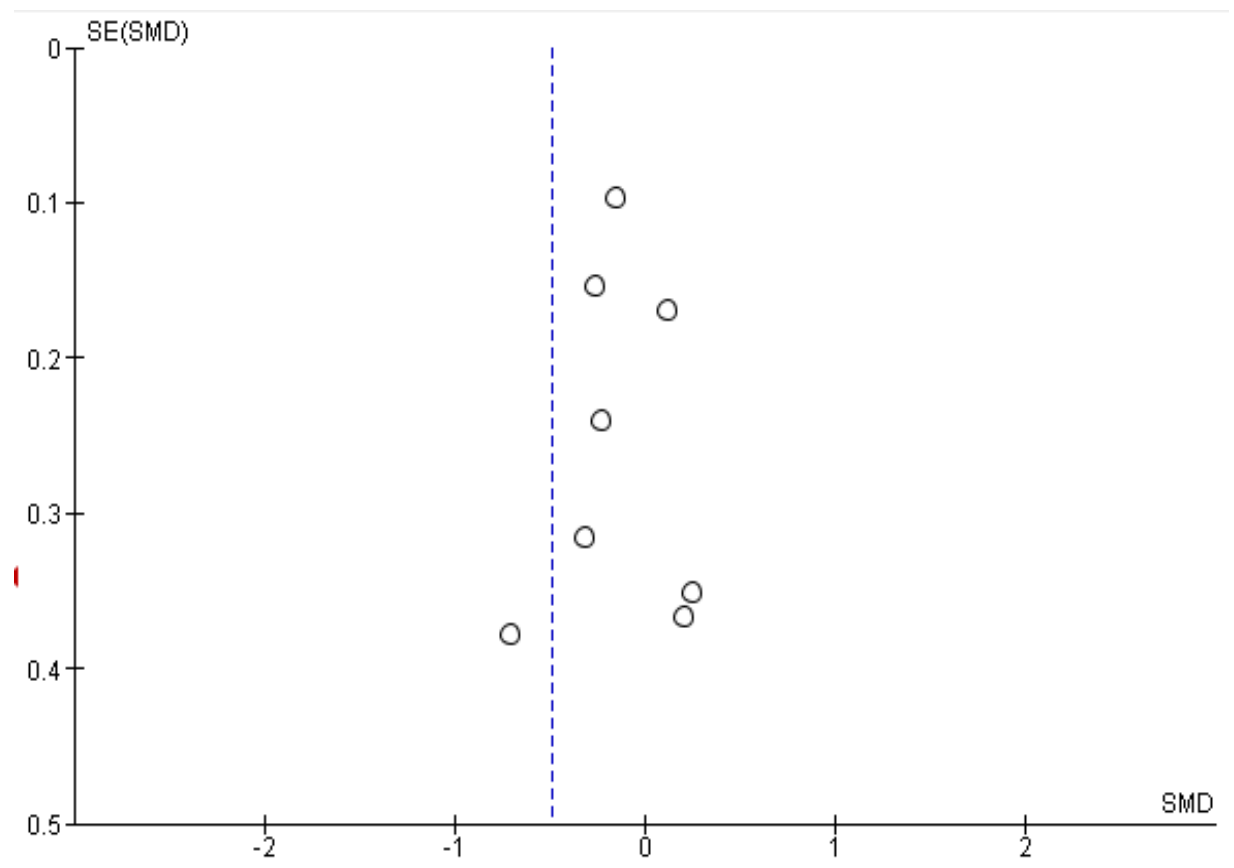

Figure 5. Funnel plot of diastolic blood pressure

The interpretation of the results of the meta-analysis can be seen in Figure 4, for the forest plot of diastolic blood pressure and Figure 5, for the funnel plot of diastolic blood pressure. Based on the results of the analysis using RevMan 5.3 software, it is known that there is high heterogeneity (I2=92\%; $\mathrm{p}<0.001$ ) so that the distribution of data is declared heterogeneous (Random Effect Model). Acupuncture therapy was less effective in reducing diastolic blood pressure with Standardized Mean Different (SMD) by o.49 compared to sham acupuncture $(\mathrm{p}=0.06)$.

A funnel plot is a plot that describes the size of the effect of each study on an 
estimate of its accuracy which is usually the standard error. Figure 5 shows the existence of publication bias which is indicated by the asymmetry of the right and left plots. SE value $<0.5$.

\section{DISCUSSION}

The systematic review and meta-analysis of this study raised the topic of the effect of acupuncture on lowering blood pressure in hypertensive patients. This meta-analysis study uses research article sources that have controlled for confounding factors. Confounding factors are factors that cannot be avoided in research, can be controlled and affect the results of invalid studies (Murti, 2018). This study controls confounding factors that can be seen from the inclusion and exclusion in this study. There were 9 articles that passed the inclusion and exclusion criteria from a number of primary studies that were included in this study.

The results of a meta-analysis from a Randomized Controlled Trial (RCT) study showed that acupuncture was able to significantly reduce systolic blood pressure, but acupuncture was not significant in reducing diastolic blood pressure, so it can be collaborated with other treatment therapies to achieve blood pressure targets and control blood pressure.

The insignificant decrease in DBP may be caused by the condition of the patient with chronic hypertension. Patients with chronic hypertension experience thickening of the walls of the heart and stiffening of the blood vessels. This causes the heart to still be able to pump blood, but is less able to receive blood, so the decrease in diastolic pressure tends to be insignificant.

This is in line with the research of Zhao et al. (2019) which states that acupuncture combined with medical treatment (antihypertensive drugs) is better in reducing SBP, DBP, increasing effectiveness and overcoming TCM syndrome in hypertensive patients. Therefore, acupuncture is recommended as an additional therapy for medical treatment, so that the use of antihypertensive drugs can be done with smaller doses to avoid side effects of antihypertensive drugs, so that adherence to taking antihypertensive drugs can be optimized (Zhang et al., 2014).

Acupuncture is safe in lowering blood pressure in cases of pre-eclampsia in labor and postpartum, if performed by experts and professionals. Handling cases of hypertension in the elderly with acupuncture therapy combined with pharmacological therapy has proven to be more effective than using only pharmacological therapy (Lazuardi et al., 2018).

Acupuncture has minor side effects such as pain, bleeding, minimal hematoma but in a large sample there were no deaths or permanent injuries from acupuncture (Lee et al., 2009). Therefore, acupuncture is proven to be safe and can be used in the treatment of hypertension.

The limitation in this study is search bias because in this study only 7 electronic databases were used, namely Google Scholar, MEDLINE/PubMed, Science Direct, Hindawi, BMC, Europe PMC and Springer Link, thus ignoring other search sources. Language bias because in this study only articles in English and Indonesian were used. The articles used are only articles that have been published, thus ignoring the articles that have not been published.

It is hoped that further researchers can conduct research related to the effectiveness of acupuncture in hypertensive patients with a larger sample, wider language used, and with different research locations for the development of further similar research. Essential hypertension is a chronic cardiovascular disease, so the long-term 
Hapsari et al./ Acupuncture Therapy on Reducing Blood Pressure in Hypertension Patients

effect of treatment is of great concern to patients. A longer follow-up period is recommended to determine the long-term effectiveness of acupuncture.

\section{AUTHOR CONTRIBUTION}

Faricha Indra Hapsari as the main researcher is the executor of the research, collecting related articles, conducting research, data analysis, data processing and writing research manuscripts. Setyo Sri Rahardjo played a role in preparing the research framework, research design and writing research manuscripts. Hanung Prasetya plays a role in developing ideas, processing research data, and preparing research manuscripts.

\section{FUNDING AND SPONSORSHIP}

This study is self-funded.

\section{CONFLICT OF INTEREST}

There is no conflict of interest in this study.

\section{ACKNOWLEDGEMENT}

We would like to thank the database providers, namely Google Scholar, MEDLINE/ PubMed, Science Direct, Hindawi, BMC, Europe PMC and Springer Link.

\section{REFERENCES}

Depkes (2018). Hipertensi membunuh diam-diam, ketahui TD anda (Hypertension kills silently, know your BP). http://www.depkes.go.id/article/view/18051600004/hipertensimembun uhdiamdiam-ketahui-tekanan-darahanda.html(diakses 19 Februari 2021)

CEBMa (2014). Critical appraisal. Amsterdam: Center for evidence based management. Retrieved from https://cebma.org/resourcesandtools/what is-criticalappraisal/.
Huang KY, Huang CJ, Hsu CH (2020). Efficacy of acupuncture in the treatment of elderly patients with hypertension in home health care: a randomized controlled trial. J Altern Complement Med. 26: 273-281. https://doi:10.1089/acm.2019.0172.

Kim HM, Cho SY, Park SU, Sohn IS, Jung WS, Moon SK, Park JM, Ko CN, Cho $\mathrm{KH}$ (2012). Can acupuncture affect the circadian rhythm of blood pressure? A randomized, double-blind, controlled trial. J Altern Complement Med (New York). 18(10): 918-923. https://doi.org/10.1089/acm.2011.0508.

Lazuardi D, Mihardja H, Srilestari A, Marbun (2018). Effect of press needles on PC6, MA-IC 7, and MA-TF 1 accupuncture points on blood pressure and quality of life in essential hypertension patients. J Phys Conf Ser. 1073(6). https://doi.org/10.1088/1742-6596/1073/6/062048.

Lee H, Kim SY, Park J, Kim YJ, Lee H, Park HJ (2009). Acupuncture for lowering blood pressure: systematic review and meta-analysis. Am J Hypertens. 22(1): 122-128.https://doi.org/10.1038/ajh.2008.311.

Li P, Stephanie C, Tjen AL, Ling C, Dong ML, Jeanette P, Sivarama V, et al. (2015). Long-lasting reduction of blood pressure by electroacupuncture in patients with hypertension randomized controlled trial. Med Acupunc. 27: 253-266. https://doi:10. 1089/acu.2015.1106.

Liu Y, Ji EP, Kyung MS, Minhee L, Hee J, Ae RK, So YJ, et al. (2015). Acupuncture lowers blood pressure in mild hypertension patients: a randomized, controlled, assessor-blinded pilot trial. Complement Ther Med. 23: 658-665. 
Hapsari et al./ Acupuncture Therapy on Reducing Blood Pressure in Hypertension Patients

https://www.sciencedirect.com/science/article/pii/So9652299150010 53.

Macklin EA, Wayne PM, Zusman RM, et al. (2006). Stop hypertension with the acupuncture research program (SHARP): results of a randomized, controlled clinical trial. Hyp. 48: 838845.https://doi:10.1161/o1.HYP.0000 $241090.28070 .4 \mathrm{c}$

Maheshkumar K, Deenadayalan B, Akila A, Venugopal V, Poonguzhali S (2020). Effectiveness of taichong (LR3) acupuncture point on blood pressure in patients with hypertension: a randomized sham control trial. Adv Integr Med. 8(1): 58-62. https://doi.org/10.1016/j.aimed.2020.05.002.

Murti B (2018). Prinsip dan metode riset epidemiologi (5th ed). Surakarta: Program Studi Ilmu Kesehatan Masyarakat, Program Pascasarjana, Universitas Sebelas Maret.

Park JM, Shin AS, Park, SU, Sohn, IS, Jung WS, Moon SK (2010). The acute effect of acupuncture on endothelial dysfunction in patients with hypertension: a pilot, randomized, doubleblind, placebo-controlled crossover trial. J Altern Complement Med (New York). 16(8): 883-888. https://doi.org/10.1089/acm.2009.0427.

Rodiah N (2013). Perbandingan efek akupunktur telinga dengan akupunktur tubuh terhadap TD dan kadar nitrit oksida pada pasien hipertensi esensial di Puskesmas Kecamatan Jatinegara https://lib.ui.ac.id/naskahringkas/201509/SP-Nyimas\%2oRo diah

Suhana (2014). Pengaruh penanaman benang catgut terhadap kadar nitrit oksida dan TD pada pasien hipertensi esensial (Effect of catgut thread implantation on nitric oxide levels and BP in essential hypertension patients). Tesis. Universitas Indonesia.

Wang J, Xingjiang X, Wei L (2013). Acupuncture for essential hypertension. Int J Cardiol. 169(2013): 317-326. https://DOI:10.1016/j.ijcard.2013.09.001.

Yin C, Seo B, Park HJ, Cho M, Jung W, Choue R, Kim C, Park HK, Lee H, Koh, $\mathrm{H}$ (2007). Acupuncture, a promising adjunctive therapy for essential hypertension: a double-blind, randomized, controlled trial. Neurol Res. 29(1): S98-S103. https://doi.org/10.1179/016164107X172220.

Yulanda G, Lisiswanti (2017). Penatalaksanaan hipertensi primer (Management of primary hypertension). Medical Journal of Lampung University. 6(1). Available at http://juke.kedokteran.unila.ac.id/index.php/majority/ issue/view/69.

Zheng H, Li J, Li Y, Zhao L, Wu X, Chen J, Li X, Huang YL, et al. (2019). Acupuncture for patients with mild hypertension: a randomized controllled trial. J Clin Hypertens. 21: 412420. https://doi.org/10.1111/jch.13490.

Zhang L, Shen P, Wang S (2014). Acupuncture treatment for hypertension: a case study. Acupuncture in medicine : BMJ. 32(1): $\quad 73-76 . \quad$ https://doi:10.1136/acupmed-2013-010407

Zhao H, Li D, Li Y, Yang Y, Liu Y, Li J, Mao $J$ (2019). Efficacy and safety of acupuncture for hypertension: an overview of systematic reviews. Complement Ther Clin Pract. 34: 185-194. https://doi.10.1016/j.ctcp.2018. 12.003 . 